\title{
Mediation of Fibrin-induced Release of von Willebrand Factor from Cultured Endothelial Cells by the Fibrin $\beta$ Chain
}

\author{
Julie A. Ribes, * Feng Ni, ${ }^{5}$ Denisa D. Wagner, ${ }^{\ddagger}$ and Charles W. Francis ${ }^{\ddagger}$ \\ ${ }^{*}$ Department of Pathology and Laboratory Medicine and ${ }^{\ddagger}$ Hematology Unit, Department of Medicine, University of Rochester School of \\ Medicine and Dentistry, Rochester, New York 14642; and ${ }^{\S}$ Baker Laboratory of Chemistry, Cornell University, Ithaca, New York 14853
}

\begin{abstract}
The exposure of endothelial cells (EC) to fibrin has been shown to stimulate the rapid release of von Willebrand factor (vWf) from storage sites in Weibel-Palade bodies. We have now investigated the fibrin structural features required for stimulation of release. The role of fibrinopeptide cleavage was examined by preparing fibrin with thrombin to remove both fibrinopeptide A (FPA) and fibrinopeptide B (FPB) and with reptilase or Agkistrodon contortrix procoagulant to selectively remove FPA or FPB, respectively. vWf release was found to require FPB cleavage, whereas removal of FPA and Factor XIII. cross-linking of fibrin were without effect. The dependence of release on FPB cleavage suggested that a site involving the $\mathrm{NH}_{2}$ terminus of the $\beta$ chain could mediate $\mathrm{vWf}$ secretion. To test this hypothesis, $B \beta$ chain derivatives were prepared and examined for their capacity to induce release. Purified $B \boldsymbol{\beta}$ chain had no effect on release at a concentration of $20 \mathrm{nM}$ but stimulated release from $26 \pm 6 \%$ of cells at $200 \mathrm{nM}$, the maximum solubility. However, after thrombin cleavage of FPB, release occurred from $36 \pm 9 \%$ of cells at $20 \mathrm{nM}$ and from $60 \pm 7 \%$ at $200 \mathrm{nM}$, both significantly greater than before cleavage. FPB and $B \beta 1-42$ showed no activity, whereas $\beta 15-42$, representing the $\mathrm{NH}_{2}$ terminus of the thrombin cleaved $\beta$ chain, stimulated significant release at concentrations of 0.1 and $1 \mathrm{mM}$. We conclude that FPB cleavage from fibrin is required for stimulation of $\mathrm{vWf}$ release from $\mathrm{EC}$ and that this is mediated by a site that includes the $\mathrm{NH}_{2}$ terminus of the $\beta$ chain.
\end{abstract}

\section{Introduction}

Fibrin interacts with endothelial cells at sites of inflammation, vascular injury, and thrombosis, resulting in several effects on hemostasis and endothelial cell (EC) ${ }^{1}$ function. Exposure of a confluent endothelial monolayer to fibrin causes cell retrac-

D. D. Wagner's present address is Center for Hemostasis and Thrombosis Research, New England Medical Center, and Tufts University School of Medicine, Boston, MA 02111. Address reprint requests to Dr. Charles W. Francis, Hematology Unit, Box 610, University of Rochester Medical Center, 601 Elmwood Avenue, Rochester, NY 14642.

Received for publication 22 September 1988 and in revised form 20 March 1989.

1. Abbreviations used in this paper: EC, endothelial cell; FPA, fibrinopeptide A; FPB, fibrinopeptide B; TFA, trifluoracetic acid.

J. Clin. Invest.

(C) The American Society for Clinical Investigation, Inc.

$0021-9738 / 89 / 08 / 0435 / 08 \$ 2.00$

Volume 84, August 1989, 435-442 tion, disruption of cellular organization, and separation of the monolayer into migratory cells (1). Both fibrin and fibrin degradation products have been shown to stimulate EC migration (1-3) and disorganization during angiogenesis (4-6). EC exposed to fibrin increase secretion of both prostacyclin, a potent vasodilator and inhibitor of platelet aggregation, and tissue plasminogen activator, an inducer of fibrinolytic activity (7).

Fibrin may also affect hemostasis by causing release of $\mathrm{vWf}$ from its storage sites in the Weibel-Palade bodies of EC (8). vWf is a large adhesive glycoprotein synthesized by EC (9) and megakaryocytes $(10,11)$ that is required for adhesion of platelets to the subendothelium at sites of vascular injury $(12,13)$ and also supports the platelet interactions resulting in formation of platelet aggregates $(14,15)$. The importance of $\mathrm{vWf}$ in hemostasis is reflected in the occurrence of the bleeding disorder, von Willebrand's disease, resulting from deficient or defective vWf (16). vWf is structurally heterogeneous, consisting of disulfide-bound multimers varying in molecular weight from 500,000 to $20,000,000$ as shown by SDS agarose gel electrophoresis $(17,18)$, with the larger forms having greater biological activity than the smaller (19). Because vWf stored in EC Weibel-Palade bodies consists of only the largest multimers $(20,21)$, fibrin-induced secretion can provide highly functional vWf to facilitate local hemostasis.

Fibrinogen is a bivalent molecule composed of six polypeptide chains, two each of the $\mathrm{A} \alpha, \mathrm{B} \beta$, and $\gamma$ chains. These chains are disulfide bonded near their amino termini, to form a central domain with the carboxyl ends of the chains extending laterally, forming two lateral domains (22). Thrombin cleaves fibrinogen near the amino ends of the $A \alpha$ and $B \beta$ chains liberating fibrinopeptide A (FPA) and fibrinopeptide B (FPB) (23, 24), and generating fibrin monomers that polymerize to form an insoluble gel. Fibrin may be further stabilized by the Factor $\mathrm{XIII}_{\mathrm{a}}$-catalyzed formation of intermolecular $\epsilon$ - $(\gamma$-glutamyl $)$ lysine isopeptide bonds between $\gamma$ chains of adjacent monomers (25) and also among two or more $\alpha$ chains $(26,27)$. Stabilized fibrin forms the supporting matrix of a hemostatic plug or thrombus and is proteolytically degraded by the fibrinolytic system.

Our previous studies (8) indicated that $\mathrm{vWf}$ release was stimulated within $10 \mathrm{~min}$ of exposure of EC to polymerized fibrin. Specific structural features of fibrin were required for release because fibrin made with reptilase, a snake venom that cleaves only FPA and produces non-cross-linked fibrin (28), was nonstimulatory. In this report, we have investigated the structural features of fibrin and fibrin fragments necessary to support $\mathrm{vWf}$ release from EC.

\section{Methods}

Fibrinogen and fibrinogen-cleaving enzymes. Lyophilized human fibrinogen (Grade L) was obtained from Helena Laboratories (Beaumont, TX), and copurifying Factor XIII was inactivated with acid-urea treatment as described elsewhere (27). Factor XIII inhibition was con- 
firmed by demonstrating absence of cross-linked $\gamma$ chains by SDSPAGE of the reduced polypeptide chains of fibrin prepared after clotting by thrombin in the presence of $10 \mathrm{mM}$ calcium chloride. Human thrombin $(3,250 \mathrm{U} / \mathrm{mg})$, which cleaves both FPA and FPB, and reptilase snake venom, which cleaves only FPA, were obtained from Calbiochem-Behring Corp. (La Jolla, CA) and Abbott Laboratories (North Chicago, IL), respectively. The FPB cleaving procoagulant fraction of the snake venom from Agkistrodon contortrix (Sigma Chemicals Co., St. Louis, MO) was partially purified by DEAE cellulose chromatography as described elsewhere (29). Procoagulant fractions having no fibrinolytic activity were identified as those that yielded a firm clot after a $3-\mathrm{h}$ incubation at $37^{\circ} \mathrm{C}$ with fibrinogen $(2.3$ $\mathrm{mg} / \mathrm{ml}$ ) and that did not lyse with continued incubation for $18 \mathrm{~h}$. These column fractions were pooled and stored at $-20^{\circ} \mathrm{C}$. The protein concentrations in pooled fractions were determined to be $90 \mu \mathrm{g} / \mathrm{ml}$ using the Bradford method (30).

Preparation of clots. Non-cross-linked fibrin was prepared from 3 $\mathrm{mg} / \mathrm{ml}$ of Factor XIII-deficient fibrinogen in HBSS with $10 \mathrm{mM}$ calcium chloride and $5 \times 10^{-3} \mathrm{U} / \mathrm{ml}$ thrombin, 1.1 batroboxin unit $/ \mathrm{ml}$ of reptilase or $40 \mu \mathrm{g} / \mathrm{ml}$ of procoagulant column pool of the contortrix venom. $0.7-\mathrm{ml}$ aliquots were clotted in a humidity chamber for $6-18 \mathrm{~h}$. Cross-linked fibrin was prepared in the same way with the addition of 1 $\mathrm{U} / \mathrm{ml}$ of preactivated Factor XIII before clotting. Factor XIII purified from human placenta (Behringwerke Hoechst-Roussel, Somerville, $\mathrm{NJ}$ ) that contained only a chains were activated with $1 \mathrm{U} / \mathrm{ml}$ thrombin in $10 \mathrm{mM}$ calcium chloride at $37^{\circ} \mathrm{C}$ for $30 \mathrm{~min}$, after which the thrombin was inhibited by adding $10 \mathrm{U} / \mathrm{ml}$ hirudin (Sigma Chemical Co.). Because fibrinopeptide cleavage by the contortrix enzyme is temperature dependent $(29,31)$, clots formed with this enzyme were prepared at $4^{\circ} \mathrm{C}$, favoring cleavage of FPB, whereas thrombin and reptilase clots were formed at $25^{\circ} \mathrm{C}$. All clots were rinsed three times with HBSS containing $1 \mathrm{U} / \mathrm{ml}$ hirudin at $25^{\circ} \mathrm{C}$ before incubation with cells. Supernatants from contortrix clots were prepared by removing the fibrin and centrifuging at $12,000 \mathrm{~g}$ for $2 \mathrm{~min}$. The supernatant from a single clot was added to $1 \mathrm{ml}$ of media containing $10 \mathrm{U} / \mathrm{ml}$ hirudin and added to the EC. Polypeptide chain composition of the fibrin was assessed after disulfide bond reduction by electrophoresis on 7\% SDS polyacrylamide gels (32) after staining with Coomassie blue.

Analysis of fibrinopeptide cleavage. Duplicates of clots used in release assays were formed for quantitative analysis of fibrinopeptide cleavage. For each clot, the fibrin was removed with a wooden stick, and the clot liquor was collected and centrifuged at $12,000 \mathrm{~g}$ for $2 \mathrm{~min}$. The supernatants were heated for $30 \mathrm{~min}$ at $100^{\circ} \mathrm{C}$ and then centrifuged for $30 \mathrm{~min}$ at $12,000 \mathrm{~g}$ to remove denatured, precipitated proteins. Samples of $50 \mu \mathrm{l}$ of clot supernatant and $150 \mu \mathrm{l}$ of $0.09 \%$ aqueous trifluoroacetic acid (TFA) were injected into a $\mathrm{C} 18$ analytical reverse phase HPCL column (Radpak; Waters Associates, Milford, MA) connected to a chromatograph (model 8000; Spectra-Physics, Inc., Mountain View, CA) with a compression module (Model RCM-100; Waters Associates). Fibrinopeptides were eluted from the column at a flow rate of $1 \mathrm{ml} / \mathrm{min}$ with an isocratic flow phase of $80 \%$ aqueous TFA and $20 \%$ acetonitrile containing $0.09 \%$ TFA. Three peaks could be identified on the basis of comparative migration with standards of FPA, FPB, and phosphorylated FPA prepared from human fibrinogen as described previously (33). Peptide B $\beta 2-14$ (FPB with a deletion at the $\mathrm{NH}_{2}$ terminus) was identified by amino acid analysis in supernatants of clots prepared with thrombin or contortrix (data not shown). The amount of fibrinopeptide in each sample was determined by quantitative analysis of the peak areas in the HPLC chromatograms of the peptides, which were calibrated against standards of fibrinopeptides. For each clot, the percentage of theoretical yield of FPA represented the sum of both FPA and phosphorylated FPA, whereas the percentage of FPB represented the sum of FPB and B $\beta 2-14$.

Amino acid analysis of purified peptides. Analysis of the amino acid compositions of the purified peptides and the quantitative determination of standard fibrinopeptides were carried out with an amino acid analysis system (Pico Tag; Waters Associates) at the Cornell University Biotechnology Program Facility. The peptide samples were hydrolyzed and derivatized according to the method of Bidlingmeyer and colleagues (34).

Preparation of fibrinogen B $\beta$ chain and peptides. To prepare $\mathrm{B} \beta$ chain, fibrinogen was dissolved after reduction and $S$-carboxymethylation (35) in $0.01 \mathrm{M}$ sodium phosphate, $0.01 \mathrm{M}$ Tris, $8 \mathrm{M}$ urea, and the solution was adjusted to $\mathrm{pH} 7$ with phosphoric acid. The fibrinogen chains were then chromatographed on a column of DEAE-Sephacel ( 1 $\times 33 \mathrm{~cm}$ ) at a flow rate of $16 \mathrm{ml} / \mathrm{h}$ using a buffer gradient as described by Stathakis and colleagues (36). Protein containing peaks were pooled, dialyzed against distilled water and lyophilized. The pool containing carboxymethylated $B \beta$ chains was identified by $7 \%$ SDS PAGE and comparison with reduced fibrinogen standard.

A plasmin digest of fibrinogen was prepared using a modification of the methods of Kudryk and colleagues (37). Fibrinogen was diluted to $4 \mathrm{mg} / \mathrm{ml}$ in $0.037 \mathrm{M}$ Tris, $0.15 \mathrm{M}$ sodium chloride, $0.1 \%$ sodium

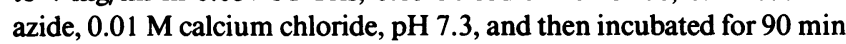
at $37^{\circ} \mathrm{C}$ with $100 \mathrm{U} / \mathrm{ml}$ streptokinase (Kabi Vitrum, Stockholm). The digest was filtered through a $10,000-M_{\mathrm{r}}$ cutoff filter (Amicon Corp., Lexington, MA) and the filtrate was found to contain $30 \mu \mathrm{g} / \mathrm{ml}$ protein by Bradford analysis (30). A portion of the filtrate was incubated with 1 $\mathrm{U} / \mathrm{ml}$ thrombin for $30 \mathrm{~min}$ and then treated with $10 \mathrm{U} / \mathrm{ml}$ hirudin to inhibit the thrombin activity.

B $\beta 1-42$ was prepared from plasmic digests of human fibrinogen as described by Skogen et al. (38). HPLC purification was conducted on a $250 \times 10 \mathrm{~mm}$ Hi-Pore-318 C18 semipreparative reverse phase column (Bio-Rad Laboratories, Rockville Center, NY) with a biphasic linear $0-25 \%$ acetonitrile gradient (38) generated by an automated gradient controller and pump (Model 510; Waters Associates). Absorbance was detected at $214 \mathrm{~nm}$ on an absorbance detector (model 441; Waters Associates). Polypeptide-containing peaks were collected, lyophilized, and analyzed for amino acid composition as described above (34). Material from selected peaks was redissolved in a minimum volume of $0.02 \mathrm{M}$ Tris-maleate, $0.1 \%$ sodium chloride, $0.01 \mathrm{M}$ calcium chloride, pH 7.4, and treated with $10 \mathrm{U} / \mathrm{ml}$ thrombin to identify thrombin-sensitive peptides. After a 1-h incubation, the peptides were rechromatographed on the same column and the peaks produced by the thrombin cleavage, B $\beta 1-14$ (FPB), B $\beta 2-14$, and $\beta 15-42$, were collected, lyophilized, and analyzed for amino acid composition (34).

$\beta 15-42$ was synthetically prepared by a modification of the solidphase peptide synthesis procedure $(39,40)$ using a peptide synthesizer (Model 430A; Applied Biosystems, Inc., Foster City, CA). The $t$-butoxy-carbonylamino acids were sequentially coupled as symmetric anhydrides onto a phenyl-acetamidomethyl $\left(\mathrm{OCH}_{2} \mathrm{PAM}\right)$ resin (Applied Biosystems, Inc.) with double coupling cycles used for all arginine residues. The remainder of the synthesis, purification, and characterization of the peptide were conducted as described (40). Peptide $\beta 1$ 5-18 (GHRP) was purchased from Sigma Chemical Co.

Cell culture and immunofluorescence. Human umbilical vein EC were grown in culture as described elsewhere $(41,42)$. Primary cultures plated on glass coverslips were grown in McCoy's 5A media (Flow Laboratories, Inc., McLean, VA) containing $20 \%$ fetal bovine serum (Hyclone Laboratories, Logan, UT). Fibrin stimulation of vWf release with preformed clots was carried out as described (8) except that all incubations were conducted at $25^{\circ} \mathrm{C}$ instead of $37^{\circ} \mathrm{C}$ because the contortrix-formed fibrin dissociated above $25^{\circ} \mathrm{C}$ (31). For vWf release stimulation assays using peptides, all solutions were made in McCoy's 5A medium with $20 \%$ FCS and $10 \mathrm{U} / \mathrm{ml}$ hirudin. Coverslips were placed in individual $16-\mathrm{mm}$ culture wells in a 24-multiwell culture plate (Corning Glass Works, Corning, NY). Each coverslip was covered with $200 \mu \mathrm{l}$ of peptide solution and incubated at $37^{\circ} \mathrm{C}$ for varying times. Indirect immunofluorescence staining of cells with anti-vWf antiserum and quantitation of $\mathrm{vWf}$ release followed procedures described previously (42).

For metabolic labeling, EC were grown in plastic flasks to $80 \%$ confluency in McCoy's $5 \mathrm{~A}$ media and then $25 \mu \mathrm{Ci} / \mathrm{ml}$ of $\left[{ }^{35} \mathrm{~S}\right]$ cysteine (Amersham Corp., Arlington Heights, IL) was added and the cells cultured an additional $3 \mathrm{~d}$. After a 6-h chase with unlabeled media, the cultures were washed three times with Hank's buffer and then incu- 
bated with potential secretagogues in media containing $10 \mathrm{U} / \mathrm{ml}$ hirudin for $3 \mathrm{~h}$. The media was then collected and vWf was immunopurified as described (43) using rabbit anti-human vWf antiserum (Calbiochem-Behring Corp., La Jolla, CA). The immunopurified vWf was electrophoresed after disulfide reduction on SDS $5 \%$ polyacrylamide gels (32) followed by autoradiography, and release was quantitated by densitometric scanning of the 220-kD chain (Quick-Scan, Jr., TLC; Helena Laboratories, Beaumont, TX).

Statistical analysis. Comparison of means was preformed using the two-tailed $t$ test. Variance is described as \pm SEM.

\section{Results}

EC stimulation by fibrin. Cross-linked and non-cross-linked fibrin were prepared using thrombin, reptilase, or contortrix to remove fibrinopeptides selectively, and the polypeptide chain composition was characterized by SDS-PAGE (Fig. 1). The $\gamma$ chains for all three types of non-cross-linked fibrin demonstrated the same mobility as did fibrinogen, consistent with absence of cleavage in this chain. Upon cross-linking (Fig. 1), the $\gamma$ chains dimerized, as evidenced by the disappearance of monomers and appearance of a $\gamma \gamma$ band not found in noncross-linked samples. Cleavage of FPB from the B $\beta$ chain was seen with thrombin and contortrix enzyme as an increased migration of the $\beta$ chain as compared with the $\mathrm{B} \beta$ chain present in fibrinogen and reptilase fibrin. Cleavage of FPA from the thrombin and reptilase fibrin also appeared as an increased mobility of the $\alpha$ chains compared with the A $\alpha$ chain fibrinogen standard. Cross-linking of the $\alpha$ chain led to a decrease in

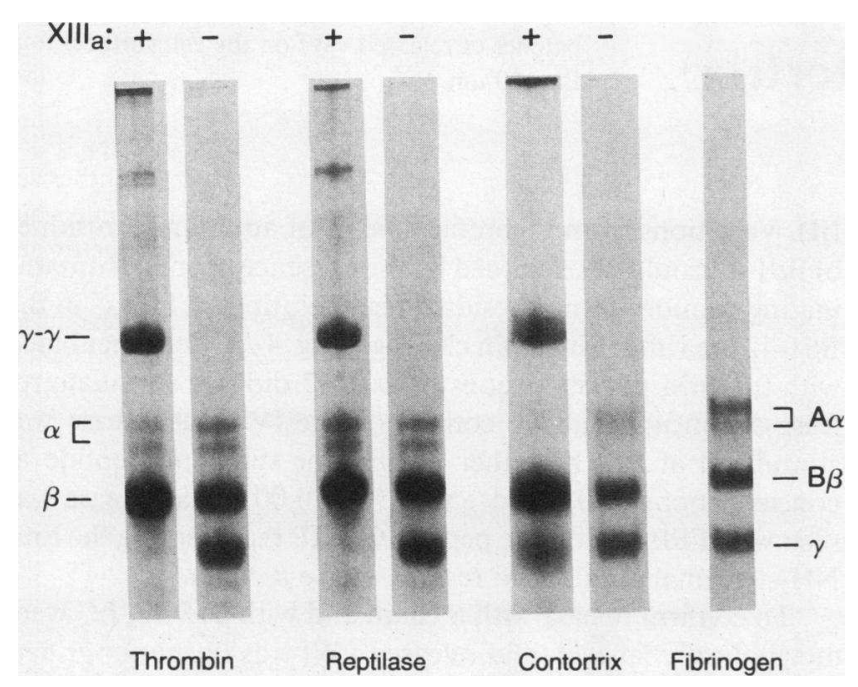

Figure 1. SDS-PAGE of fibrin. Fibrin was prepared using thrombin, reptilase, or contortrix procoagulant in the presence or absence of Factor $\mathrm{XIII}_{\mathbf{a}}$ for cross-linking. After dissolution with reduction, the polypeptide chains were separated by $7 \%$ SDS-PAGE. In the noncross-linked fibrin, $\gamma$ chains are present as monomers that are replaced by $\gamma$ dimers in cross-linked samples. B $\beta$ chains in fibrinogen and reptilase fibrin demonstrate slower migration compared with the $\beta$ chains present in fibrin made with contortrix procoagulant or thrombin. Similarly, A $\alpha$ chains in the fibrinogen are replaced by faster migrating $\alpha$ chains in fibrin prepared with thrombin or reptilase. In the cross-linked fibrin, heterogenous high relative molecular mass cross-linked polymers are formed from the A $\alpha$ chains, leading to the decreased intensity of the $A \alpha$ band, and the appearance of bands migrating more slowly than the $\gamma-\gamma$ bands. protein present in the monomeric bands and the formation of higher molecular weight $\alpha$-polymer bands migrating more slowly than the $\gamma \gamma$ chain, with some failing to enter the gel. FPA cleavage in the contortrix clot could not be readily demonstrated because this enzyme cleaved the proteolytically sensitive, carboxy-terminal end of the $\alpha$ chain, also resulting in increased mobility (29). The extent of fibrinopeptide cleavage was determined by quantitative HPLC analysis (Table I). Thrombin cleaved both FPA and FPB completely, whereas reptilase cleaved only FPA but not FPB. The contortrix enzyme preferentially cleaved FPB at $4^{\circ} \mathrm{C}$ producing fibrin, from which $90 \%$ of FPB but only $21 \%$ of FPA was removed.

The stimulatory abilities of the fibrins was assessed after immunofluorescent staining of EC for vWf after a 10-min incubation with fibrin (Table I, Fig. 2). Control cells demonstrated diffuse perinuclear staining of the vWf reflecting the presence of the protein in the endoplasmic reticulum and Golgi apparatus, and also showed staining of the rod-shaped cytoplasmic storage granules, the Weibel-Palade bodies (Fig. 2, arrowheads). Control cells in both the presence and absence of factor XIII $_{\mathrm{a}}$ demonstrated a basal level of $\mathrm{vWf}$ secretion (Table I). After stimulation with non-cross-linked or cross-linked reptilase-made clots the vWf distribution was unchanged from untreated controls (Table I, Fig. 2). In contrast, after stimulation with non-cross-linked or cross-linked thrombin- or contortrix-made fibrin, the staining pattern of the cells changed, and the Weibel-Palade bodies were replaced by bright patches of cell surface vWf staining (Fig. 2, arrows) with nearly complete release (Table I). Neither contortrix venom alone nor the supernatant from the contortrix clots stimulated release above background. When clots were made using $5 \times 10^{3} \mathrm{U} / \mathrm{ml}$ thrombin at $4^{\circ} \mathrm{C}$ for $6 \mathrm{~h}, \mathrm{HPLC}$ analysis revealed that $53 \%$ of FPA and only $10 \%$ of FPB was removed. These clots were unable to stimulate the EC, with 10 and $26 \%$ of the cells secreting after treatment with a non-cross-linked or cross-linked clot, respectively. These data demonstrate a correlation of FPB cleavage with fibrin stimulation ability, but no apparent effect of either FPA cleavage or fibrin cross-linking.

Table I. Analysis of Fibrinopeptide Cleavage and $v$ Wf Secretion Stimulation by Preformed Fibrin Clots

\begin{tabular}{|c|c|c|c|c|}
\hline \multirow{3}{*}{$\begin{array}{c}\text { Fibrinogen cleaving } \\
\text { enzyme }\end{array}$} & \multirow{3}{*}{$\begin{array}{c}\text { FPA } \\
\text { cleaved* }\end{array}$} & \multirow{3}{*}{$\begin{array}{c}\text { FPB } \\
\text { cleaved* }\end{array}$} & \multirow{2}{*}{\multicolumn{2}{|c|}{$\begin{array}{c}\begin{array}{c}\text { Percent cells that have } \\
\text { released } \mathrm{vWf}^{\ddagger}\end{array} \\
\text { Factor XIIIa }(1 \mathrm{U} / \mathrm{ml})\end{array}$}} \\
\hline & & & & \\
\hline & & & Cross-linked & Non-cross-linked \\
\hline None & - & - & $4 \pm 1$ & $7 \pm 0.2$ \\
\hline Reptilase $(1.1 \mathrm{U} / \mathrm{ml})$ & $99 \pm 2$ & $0 \pm 0$ & $11 \pm 1$ & $8 \pm 1$ \\
\hline \multicolumn{5}{|l|}{ Thrombin } \\
\hline$\left(5 \times 10^{-3} \mathrm{U} / \mathrm{ml}\right)$ & $105 \pm 3$ & $94 \pm 5$ & $79 \pm 2$ & $92 \pm 1$ \\
\hline Contortrix & $21 \pm 1$ & $90 \pm 5$ & $83 \pm 8$ & $80 \pm 2$ \\
\hline
\end{tabular}

* Fibrinopeptide cleavage was determined by HPLC analysis of the clot liquors. Results represent the mean percentage of four to six determinations \pm SE.

‡ Primary EC cultures were incubated for $10 \mathrm{~min}$ at $25^{\circ} \mathrm{C}$ with preformed clots in media with $10 \mathrm{U} / \mathrm{ml}$ hirudin and the percent of released cells was determined by immunofluorescent staining. Results represent the mean \pm SE of 5-28 determinations. 


\section{CONTROL}
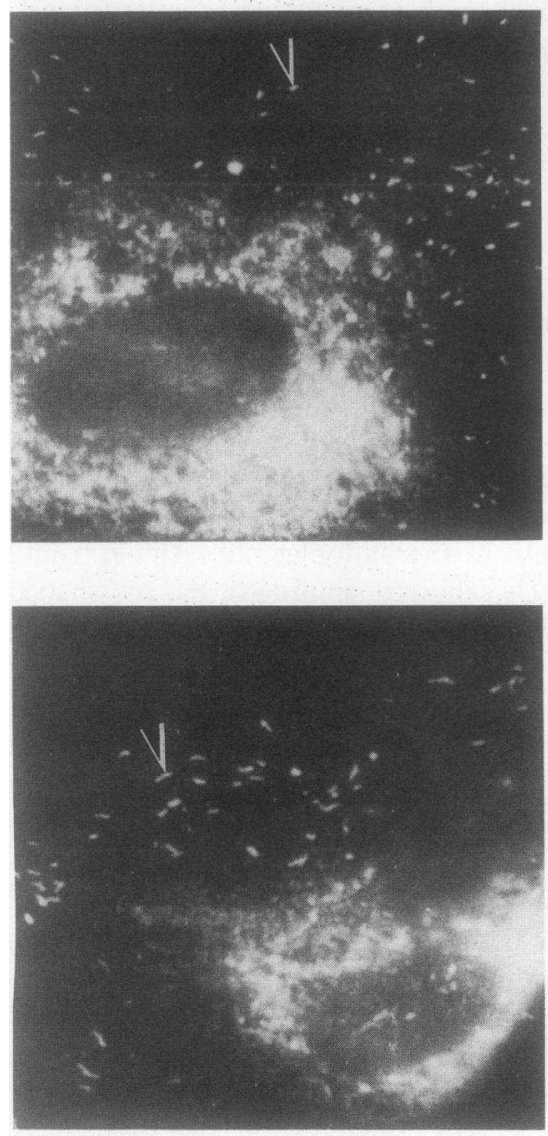

FIBRIN (Reptilase)

\section{FIBRIN (Thrombin)}
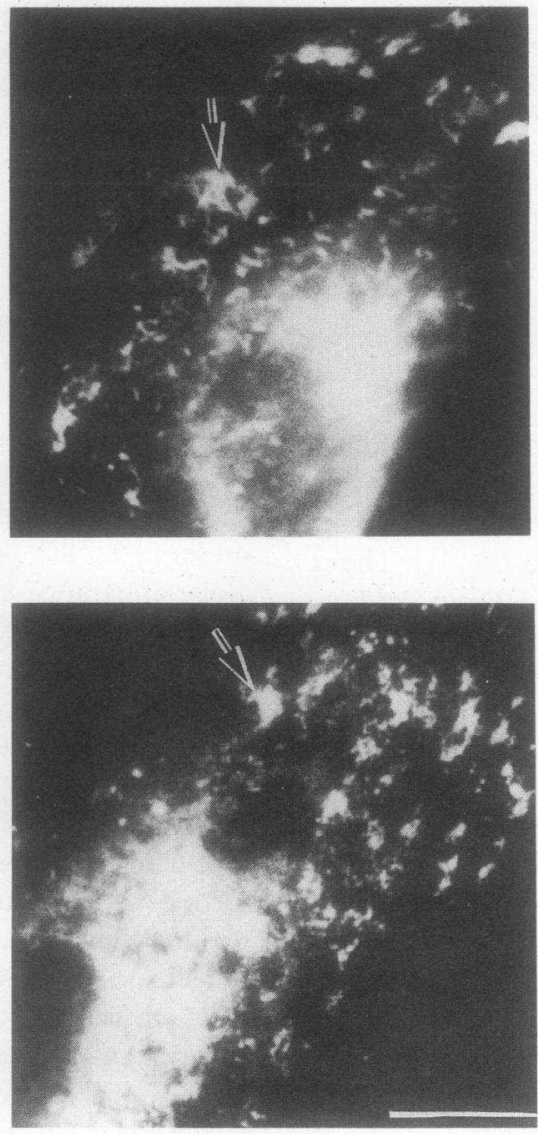

FIBRIN (Contortrix)
Figure 2. Immunofluorescent localization of vWf in EC before and after treatment with fibrin. EC grown on glass coverslips were exposed to fibrin made using thrombin, reptilase, or contortrix procoagulant. After a 10 min stimulation, the cells were fixed, permeabilized, and stained with anti-vWf antiserum. Control cells and cells exposed to fibrin made with reptilase (top and bottom left, respectively) demonstrated the perinuclear staining of $\mathrm{vWf}$ in the endoplasmic reticulum and cytoplasmic rod-shaped organelles, the Weibel-Palade bodies (arrowheads). In the cells treated with thrombin and contortrix-fibrins (top and bottom right, respectively), the Weibel-Palade bodies are replaced by bright patches of released $\mathrm{vWf}$ on the cell surface. Bar, $10 \mu \mathrm{m}$.
Endothelial cell stimulation by $B \beta$ chain and $B \beta$ chain peptides. To define further the fibrin structure needed to stimulate release, we prepared $\mathrm{B} \beta$ chain and selected peptides and examined their effect on EC. Intact $B \beta$ chain caused significant stimulation $(P<0.05)$ above background only at $200 \mathrm{nM}$, with $26 \pm 6 \%$ of the cells showing patches of release (Fig. 3). After treatment with thrombin, however, $\beta$ chain caused release above background $(P<0.01)$ at 20 and $200 \mathrm{nM}$ concentrations, stimulating $36 \pm 9$ and $60 \pm 7 \% \mathrm{SE}$, respectively. The release after thrombin cleavage was significantly above that seen with the uncleaved $\mathrm{B} \beta$ chain at $20 \mathrm{nM}(P<0.01)$ and $200 \mathrm{nM}$ $(P<0.025)$, demonstrating a dependence upon FPB cleavage for stimulation of secretion.

An $M_{\mathrm{r}}<10,000$ fraction of a plasmic digest of fibrinogen that contained $\mathrm{B} \beta 1-42$ did not stimulate $\mathrm{vWf}$ release after a 3-h incubation with EC (Table II). However, the same preparation stimulated $73 \%$ release after incubation with thrombin, indicating that thrombin-cleaved plasmic peptides retained activity. $\mathrm{B} \beta 1-42$ was purified from the $M_{\mathrm{r}}<10,000$ fraction by HPLC, eluting as a single peak after rechromatography (Fig. 4 $A$ ), and its identity was confirmed by amino acid analysis (Table III). After cleavage by thrombin $(10 \mathrm{U} / \mathrm{ml})$, two major peaks were produced (Fig. $4 \mathrm{~B}$ ) and amino acid analysis of these peaks confirmed their identity as FPB and $\beta 15-42$ (Table
III). Variations from theoretical yields of amino acid residues of $B \beta 1-42$ could be explained by the presence of small contaminating peptides seen as residual peaks eluting on HPLC in the B $\beta 1-42$ area after thrombin cleavage (Fig. $4 B$ ). Cells incubated with $0.1 \mathrm{mM}$ concentrations of $\mathrm{B} \beta 1-42$ did not stimulate release significantly above control (Table IV), but release was stimulated at $3 \mathrm{~h}$ by either purified or synthetic peptide at concentrations of 0.1 and $1 \mathrm{mM}(P<0.005)$. No release was seen with FPB or with the peptide GHRP representing the four $\mathrm{NH}_{2}$-terminal amino acid residue of the $\beta$ chain.

To confirm release with $\beta$ chain and with $\beta 15-42$, EC were metabolically labeled, and released $\mathrm{vWf}$ was immunopurified and characterized by SDS-PAGE (Fig. 5). The vWf released by A23187, $\beta$ chain, or $\beta 15-42$ was composed of equal amounts of the mature $220-\mathrm{kD}$ subunit and $100-\mathrm{kD}$ propolypeptide, confirming its release from Weibel-Palade bodies. Compared with the complete release by $\mathrm{A} 23187,200 \mathrm{nM} \beta$ chain and 100 $\mu \mathrm{M} \beta 15-42$ stimulated 36 and $23 \%$, respectively.

\section{Discussion}

The results demonstrate that the stimulation of $\mathrm{vWf}$ release from EC by fibrin requires cleavage of FPB from fibrinogen. This was established by comparing the effects of fibrin pre- 


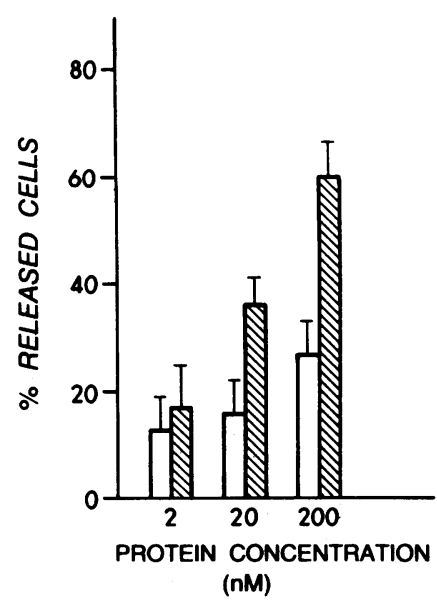

Figure 3. $\mathrm{B} \beta$ chain stimulation of $\mathrm{vWf}$ release from endothelial cells, before and after cleavage with thrombin. EC were incubated for $3 \mathrm{~h}$ with 10 $\mathrm{U} / \mathrm{ml}$ hirudin containing solutions of $\mathrm{B} \beta$ chain before (open bars) or $\mathrm{B} \beta$ chain after thrombin cleavage (hatched bars) at concentrations of 2,20 , and $200 \mathrm{nM}$. Cells were fixed, permeabilized, and stained for $\mathrm{vWf}$, and the percent of cells demonstrating patches of released vWf was determined. Cells incubated in culture medium with hirudin demonstrated a basal secretion of $11 \pm 2 \%$. Stimulation with $\mathrm{B} \beta$ chain was significantly above control $(P$ $<0.05$ ) only at $200 \mathrm{nM}$. Stimulation with thrombin treated $\mathrm{B} \beta$ chain was above control for $20 \mathrm{nM}(P<0.025)$ and $200 \mathrm{nM}$ concentrations $(P<0.01)$. The differences in stimulation at $20 \mathrm{nM}$ and 200 $\mathrm{nM}$ for the $\mathrm{B} \beta$ chains before and after thrombin cleavage were both statistically significant $(P<0.05$ and $<0.025$, respectively). Bars represent the mean of three to five determinations \pm SE.

pared with three enzymes differing in specificity for fibrinopeptide cleavage. Release of $\mathrm{vWf}$ was stimulated by fibrin prepared with either thrombin, which cleaves both FPA and FPB, or with the contortrix procoagulant, which cleaves primarily FPB (Table I). Release did not occur with exposure of EC to fibrin prepared with reptilase, which removes only FPA (Table I), confirming our prior report (8). The results further indicate that stimulation of release is independent of Factor $\mathrm{XIII}_{\mathrm{a}}$-mediated fibrin cross-linking, as both non-cross-linked and cross-linked fibrin were stimulatory after FPB cleavage (Table I). The stimulation of release by fibrin prepared with contortrix procoagulant confirms previous findings indicating that fibrin induced release was not caused by small amounts of fibrin-bound thrombin (8).

Table II. vWf Release Stimulated by Plasmic Peptides of Fibrinogen

\begin{tabular}{lc}
\hline \multicolumn{1}{c}{ Stimulant } & $\begin{array}{c}\text { \% Released } \\
\text { cells }\end{array}$ \\
\hline Control (media alone) & $10 \pm 5$ \\
Thrombin $(1 \mathrm{U} / \mathrm{ml})$ & $99 \pm 1$ \\
Thrombin $(1 \mathrm{U} / \mathrm{ml})+$ hirudin $(10 \mathrm{U} / \mathrm{ml})$ & $7 \pm 2$ \\
Plasmic peptides of fibrinogen $(30 \mu \mathrm{g} / \mathrm{ml})^{\ddagger}$ & $20 \pm 4$ \\
Plasmic peptides of fibrinogen $(30 \mu \mathrm{g} / \mathrm{ml})$, thrombin & \\
$\quad(1 \mathrm{U} / \mathrm{ml})$, and hirudin $(10 \mathrm{U} / \mathrm{ml})^{\ddagger \S}$ & $73 \pm 13$ \\
\hline
\end{tabular}

* Primary EC cultures were incubated for $3 \mathrm{~h}$ in culture medium to which stimulatory reagents were added. The percentage of released cells was determined after immunofluorescence staining. Results represent the mean of three to five observations \pm SE.

‡ TCA soluble; pass $M_{\mathrm{r}} 10,000$ filter.

${ }^{8}$ Peptides were incubated at $37^{\circ} \mathrm{C}$ with thrombin for $30 \mathrm{~min}$, and then the thrombin was incubated for $\mathbf{1 0}$ min with hirudin.
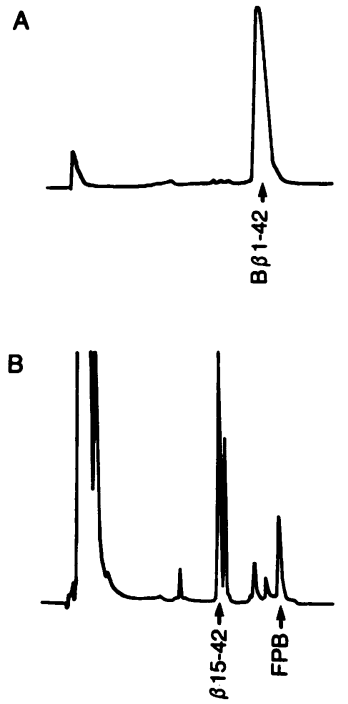

Figure 4. HPLC elution patterns of peptides derived from plasma digestion of fibrinogen. Fibrinogen was digested for $30 \mathrm{~min}$ at $37^{\circ} \mathrm{C}$ with 0.02 $\mathrm{U} / \mathrm{ml}$ plasmin, the large molecular weight proteins precipitated with $0.05 \%$ TCA and the supernatant filtered through a $10,000 M_{\mathrm{r}}$ cut-off membrane after centrifugation. The peptides were separated by HPLC on a RP-C18 318 semipreparative column (Bio-Rad Laboratories) as described by Skogen et al. (38) and peaks containing $B \beta 1-42$ were identified. The pool of $\mathrm{B} \beta 1-42$ was rechromatographed $(A)$ and was composed of a single peak. Treatment of this sample with $10 \mathrm{U} / \mathrm{ml}$ thrombin for 2 $\mathrm{h}$ at $25^{\circ} \mathrm{C}(B)$ produced two major peaks, found by amino acid analysis to be $\beta 15-42$ and FPB.
The results with purified $\mathrm{B} \beta$ chain and $\mathrm{B} \beta$ chain peptides implicate a site near the $\mathrm{NH}_{2}$ terminus of the $\beta$ chain in mediating $\mathrm{vWf}$ release. The $\mathrm{B} \beta$ chain showed minimal activity at $200 \mathrm{nM}$, whereas significant release occurred at $20 \mathrm{nM}$ after thrombin cleavage (Fig. 3). The finding that a low relative molecular mass fraction of a plasmic digest of fibrinogen stimulated release after thrombin cleavage (Table II), is also consistent with involvement of a site at the $\beta$ chain $\mathrm{NH}_{2}$ terminus, because $B \beta 1-42$ is cleaved early during plasmic degradation of fibrinogen (38) and contains the arg14-gly 15 bond that is sen-

Table III. Amino Acid Analysis of Fibrinogen Degradation Products

\begin{tabular}{|c|c|c|c|c|c|c|}
\hline \multirow{2}{*}{$\begin{array}{l}\text { Amino } \\
\text { acids }\end{array}$} & \multicolumn{2}{|c|}{$\mathrm{B} \beta 1-42^{*}$} & \multicolumn{2}{|c|}{$\beta 15-42^{\ddagger}$} & \multicolumn{2}{|c|}{$\mathrm{FPB}^{s}$} \\
\hline & Observed & Expected & Observed & Expected & Observed & Expected \\
\hline ASX & 4.7 & 4 & 1.1 & 1 & 2.8 & 3 \\
\hline GLX & 5.1 & 5 & 2.2 & 2 & 3.0 & 3 \\
\hline SER & 2.6 & 3 & 2.3 & 2 & 1.0 & 1 \\
\hline GLY & 5.2 & 6 & 4.7 & 4 & 2.0 & 2 \\
\hline HIS & 1.0 & 1 & 1.0 & 1 & 0 & 0 \\
\hline ARG & 4.3 & 5 & 4.0 & 4 & 1.1 & 1 \\
\hline THR & 1.1 & 0 & 0.3 & 0 & 0 & 0 \\
\hline ALA & 3.3 & 3 & 1.8 & 2 & 1.0 & 1 \\
\hline PRO & 5.2 & 6 & 5.4 & 6 & 0 & 0 \\
\hline TYR & 0.6 & 1 & 0.6 & 1 & 0 & 0 \\
\hline VAL & 1.3 & 1 & 0.2 & 0 & 1.0 & 1 \\
\hline MET & 1.9 & 0 & 0.1 & 0 & 0 & 0 \\
\hline CYS & 0.1 & 0 & 0.2 & 0 & 0 & 0 \\
\hline ILE & 0.6 & 1 & 0.9 & 1 & 0 & 0 \\
\hline LEU & 2.7 & 2 & 1.8 & 2 & 0 & 0 \\
\hline PHE & 2.1 & 2 & 0.1 & 0 & 1.9 & 2 \\
\hline LYS & 1.6 & 2 & 1.7 & 2 & 0 & 0 \\
\hline
\end{tabular}

* Average of 11 .

‡ Average of 5 .

$\$$ Average of 5 . 
Table IV. Release of $v W f$ from EC Stimulated by Peptides Derived from $B \beta$ Chains

\begin{tabular}{lc}
\hline \multicolumn{1}{c}{ Stimulant } & \% Released cells \\
\hline Control (medium alone) & $11 \pm 2$ \\
FPB (B $\beta 1-14)$ & $15 \pm 3$ \\
GHRP $(\beta 15-18)$ & $7 \pm 1$ \\
B $\beta 1-42$ & $17 \pm 4$ \\
$\beta 15-42(0.1 \mathrm{mM})$ & $26 \pm 2$ \\
$\beta 15-42(1 \mathrm{mM})$ & $47 \pm 3$
\end{tabular}

* EC were incubated for $3 \mathrm{~h}$ with peptides in medium containing 10 $\mathrm{U} / \mathrm{ml}$ hirudin. The peptide concentration was $0.1 \mathrm{mM}$ except as noted. The percentage of cells with release patches was determined after immunofluorescence staining. Means $\pm S E$ of four to six determinations. Stimulation by $\beta 15-42$ was significantly above control values $(P<0.005)$ at concentrations of 0.1 and $1 \mathrm{mM}$ of purified or synthetic peptide.

sitive to cleavage by thrombin. To confirm the involvement of a site at the $\beta$ chain $\mathrm{NH}_{2}$ terminus, we purified $\mathrm{B} \beta 1-42$, $\beta 15-42$, and FPB (Fig. 4) and found that only $\beta 15-42$ had stimulatory activity (Table IV). Release was confirmed by immunopurification of released vWf after exposure of EC to $\beta$ chain or $\beta 15-42$ (Fig. 5). The released vWf was composed of mature, highly processed subunits, and released in equal amount to the propolypeptide (Fig. 5), indicating that it derived from Weibel-Palade bodies (20).

None of the soluble derivatives was as active in stimulating release as intact fibrin, as these preparations stimulated less at $3 \mathrm{~h}$ than intact fibrin stimulated at $10 \mathrm{~min}$. One potential explanation for this finding is that the complete active site includes structures contained on the $\alpha$ or $\gamma$ chain present in intact fibrin but absent in the $\beta$ chain peptides. A second explanation for the slower release with peptides is that the necessary conformation of the $\beta$ chain for stimulation is stabilized in intact fibrin, and this is consistent with the greater activity of the whole $\beta$ chain, which was active at a concentration as low

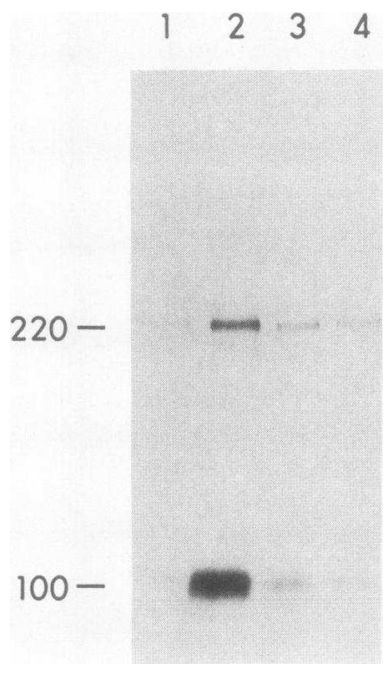

Figure 5. SDS-PAGE of metabolically labeled $\mathrm{vWf}$ released from endothelial cells. EC were metabolically labeled with $\left[{ }^{35} \mathrm{~S}\right]-$ cysteine, chased for $6 \mathrm{~h}$ in nonradioactive media, and then washed. The cultures were then incubated for three hours with medium containing $10 \mathrm{U} / \mathrm{ml}$ hirudin (lane 1 ), or medium with $10 \mathrm{U} / \mathrm{ml}$ hirudin containing $10 \mu \mathrm{M}$ A23187 (lane 2), $200 \mathrm{nM} \beta$ chain (lane 3), or $100 \mu \mathrm{M} \beta 15-42$ (lane 4). After electrophoresis and autoradiography, two bands were identified representing mature $\mathrm{vWf}(220 \mathrm{kD})$ and the $\mathrm{vWf}$ propolypeptide (100 kD). as $20 \mathrm{nM}$ (Fig. 3). Stimulation of release by the $\mathrm{B} \beta$ chain at the highest concentration (Fig. 3) may indicate that it can occasionally assume the necessary conformation for stimulation. Finally, it may be that maximum release requires cross-linking of multiple EC surface receptors that can occur with polymerized fibrin but not with soluble polypeptide chains or peptides.

Several peptides resulting from thrombin or plasmin cleavage of the $\mathrm{B} \beta$ chain $\mathrm{NH}_{2}$ terminus have been shown to be functionally active. Thrombin cleavage of the arg14-gly 15 bond creates a new $\beta$ chain $\mathrm{NH}_{2}$ terminus, and the first four amino acid residues, gly-his-arg-pro, influence fibrin polymerization $(44,45)$. Plasmin rapidly cleaves $B \beta 1-42$ from fibrinogen or $\beta 15-42$ from fibrin and can also liberate the pentapeptide $\beta 43-47$ (46). FPB and plasmic peptides of fibrinogen and fibrin have been shown to cause EC shape change and stimulation of migration in culture (47). Additional effects on EC include the reported vasoconstrictor activity of FPB (46) and the vasodilation and increased vascular permeability stimulated by $\beta 43-47(46,48)$. FPB and $B \beta 1-42$ have effects on other cell types including the stimulation of migration of neutrophils (49-51), monocytes (52), and fibroblasts $(49,50)$. Plasmic peptides of fibrinogen, including $\beta 43-47$ inhibit thymidine uptake in stimulated lymphocytes $(53,54)$ suggesting that they have immunosuppressive effects. The findings in this report demonstrate that removal of FPB is necessary for expression of $v W f$ releasing activity since neither intact fibrinogen nor $B \beta 1-42$ had activity. This indicates that EC specifically recognize the amino terminus of the $\beta$ chain, possibly by a receptor-mediated mechanism. The recent findings by Chen et al. (55) that $\beta 15-42$ inhibits platelet aggregation and binding to activated platelets is consistent with this hypothesis. Together, the evidence suggests an important role for sites near the $\mathrm{NH}_{2}$ terminus of the $\mathrm{B} \beta$ or $\beta$ chain in modulating the cellular changes accompanying hemostasis and inflammation at sites of fibrin deposition.

\section{Acknowledgments}

We thank T. W. Thannhauser and R. Sherwood for carrying out the amino acid analyses, C. Erickson-Miller for assisting with the HPLC, M. R. Jacobs for help in peptide synthesis, and Carol B. Weed and Linda Piedemonte for preparing the manuscript.

This work was supported in part by grant HL-30616 from the National Heart, Lung, and Blood Institute, National Institutes of Health. Dr. Francis is the recipient of an Established Investigatorship from the American Heart Association, New York State Affiliate.

\section{References}

1. Kadish, J. L., C. E. Butterfield, and J. Folkman. 1979. The effect of fibrin on cultured vascular endothelial cells. Tissue \& Cell. 11:99108.

2. Weimar, B., and U. Delvos. 1985. The mechanism of fibrin-induced disorganization of cultured human endothelial cell monolayers. Arteriosclerosis. 6:139-145.

3. Watanabe, K., and K. Tanaka. 1983. Influence of fibrin, fibrinogen and fibrinogen degradation products on cultured endothelial cells. Atherosclerosis. 48:57-70.

4. Olander, J. V., M. E. Bremer, J. C. Marasa, and J. Feder. 1985. 
Fibrin-enhanced endothelial cell organization. J. Cell. Physiol. 125: 1-9.

5. Thompson, W. D., R. Campbell, and T. Evans. 1985. Fibrin degradation and angiogenesis: quantitative analysis of the angiogenic response in the chick chorioallantoic membrane. J. Pathol. 145:27-37.

6. Dvorak, H. F., V. S. Harvey, P. Estrella, L. F. Brown, J. McDonagh, and A. M. Dvorak. 1987. Fibrin containing gels induce angiogenesis: implications for tumor stroma generation and wound healing. Lab. Invest. 57:673-686.

7. Kaplan, K. L., T. Mather, L. DeMarco, and S. Solomon. 1987. Fibrin stimulation of endothelial cell (EC) production of $\mathrm{PGI}_{2}$ and tissue plasminogen activator (tPA). Thromb. Haemostasis. 58:1939.

8. Ribes, J. A., C. W. Francis, and D. D. Wagner. 1987. Fibrin induces release of von Willebrand factor from endothelial cells. J. Clin. Invest. 79:117-123.

9. Jaffe, E. A., L. W. Hoyer, and R. L. Nachman. 1973. Synthesis of antihemophilic factor antigen by cultured human endothelial cells. $J$. Clin. Invest. 52:2757-2764.

10. Nachman, R., R. Levine, and E. A. Jaffe. 1977. Synthesis of factor VIII antigen by cultured guinea pig megakaryocytes. J. Clin. Invest. 60:914-921.

11. Sporn, L. A., S. I. Chavin, V. J. Marder, and D. D. Wagner. 1985. Biosynthesis of von Willebrand protein by human megakaryocytes. J. Clin. Invest. 76:1102-1106.

12. Tschopp, T. B., H. J. Weiss, and H. R. Baumgartner. 1974. Decreased adhesion of platelets to subendothelium in von Willebrand's disease. J. Lab. Clin. Med. 83:296-300.

13. Sakariassen, K. S., P. A. Bolhuis, and J. J. Sixma. 1979. Human blood platelet adhesion to artery subendothelium is mediated by factor VIII-von Willebrand factor bound to the subendothelium. Nature (Lond.). 279:636-638.

14. Hovig, T., and H. Stormorken. 1974. Ultrastructural studies on the platelet plug formation in bleeding time wounds from normal individuals and patients with von Willebrand's disease. Acta Pathol. Microbiol. Scand. A(Suppl. 248):105-122.

15. Turitto, V. T., H. J. Weiss, and H. R. Baumgartner. 1984. Platelet interaction with rabbit subendothelium in von Willebrand's disease altered thrombus formation distinct from defective platelet adhesion. J. Clin. Invest. 74:1730-1741.

16. Zimmerman, T. S., and Z. M. Ruggeri. 1987. von Willebrand Disease. Hum. Pathol. 18:140-152.

17. Hoyer, L. W., and J. R. Shainoff. 1980. Factor VIII-related protein circulates in normal human plasma as high molecular weight multimers. Blood. 55:1056-1059.

18. Martin, S. E., V. J. Marder, C. W. Francis, and G. H. Barlow. 1981. Structural studies on the functional heterogeneity of von Willebrand protein polymers. Blood. 57:313-323.

19. Ruggeri, Z. M., and T. S. Zimmerman. 1980. Variant von Willebrand's disease. Characterization of two subtypes by analysis of multimeric composition of factor VIII von Willebrand factor in plasma and platelets. J. Clin. Invest. 65:1318-1325.

20. Sporn, L. A., V. J. Marder, and D. D. Wagner. 1986. Inducible secretion of large biologically potent von Willebrand factor multimers. Cell. 46:185-190.

21. Ewenstein, B. M., M. H. Warhol, R. I. Handin, and J. S. Pober. 1987. Composition of the von Willebrand factor storage organelle (Weibel-Palade body) isolated from cultured human umbilical vein endothelial cells. J. Biol. Chem. 104:1423-1430.

22. Doolittle, R. F. 1984. Fibrinogen and fibrin. Annu. Rev. Biochem. 53:195-229.

23. Blomback, B., M. Blomback, B. Hessel, and S. Iwanaga. 1967. Structure of N-terminal fragments of fibrinogen and specificity of thrombin. Nature (Lond.). 215:1445-1448.

24. Woods, K. R., M. S. Horowitz, and B. Blomback. 1972. Effect of thrombin on the molecular weights of $\mathrm{N}$-terminal fragments of human fibrinogen. Thromb. Res. 1:113-126.
25. Chen, R., and R. F. Doolittle. 1971. $\gamma-\gamma$ cross-linking sites in human and bovine fibrin. Biochemistry. 10:4486-4491.

26. McKee, P. A., P. Mattock, and R. L. Hill. 1970. Subunit structure of human fibrinogen, soluble fibrin, and cross-linked insoluble fibrin. Proc. Natl. Acad. Sci. USA. 66:738-744.

27. Schwartz, M. L., S. V. Pizzo, R. L. Hill, and P. A. McKee. 1971. The effect of fibrin-stabilizing factor on the subunit structure of human fibrin. J. Clin. Invest. 50:1506-1513.

28. Kwaan, H. C., and G. H. Barlow. 1971. The mechanism of action of Arvin and Reptilase. Thromb. Diath. Haemorrh. 47(Suppl.):361-369.

29. Herzig, R. H., O. D. Ratnoff, and J. R. Shainoff. 1970. Studies on a procoagulant fraction of southern copperhead snake venom: the preferential release of fibrinopeptide B. J. Lab. Clin. Med. 76:451-465.

30. Bradford, M. M. 1976. A rapid and sensitive method for the quantitation of microgram quantities of protein utilizing the principle of protein-dye binding. Anal. Biochem. 72:248-254.

31. Shainoff, J. R., and B. N. Dardik. 1979. Fibrinopeptide B and aggregation of fibrinogen. Science (Wash. DC). 204:200-202.

32. Weber, K., and M. Osborn. 1969. The reliability of molecular weight determinations by dodecyl sulfate-polyacrylamide gel electrophoresis. J. Biol. Chem. 244:4406-4412.

33. Hanna, L. S., H. A. Scheraga, C. W. Francis, and V. J. Marder. 1984. Comparison of structures of various human fibrinogens and a derivative thereof by a study of the kinetics of release of fibrinopeptides. Biochemistry. 23:4681-4687.

34. Bidlingmeyer, B. A., S. A. Cohen, and T. L. Tarvin. 1984. Rapid analysis of amino acids using pre-column derivatization. $J$. Chromatogr. 336:93-104.

35. Murano, G., B. Wiman, M. Blomback, and B. Blomback. 1971. Preparation and isolation of the S-carboxymethyl derivative chains of human fibrinogen. FEBS (Fed. Eur. Biochem. Soc.) Lett. 14:37-40.

36. Stathakis, N. E., M. W. Mosesson, D. K. Galanakis, and D. Menache. 1978. Human fibrinogen heterogeneities. Preparation and characterization of $\gamma$ and $\gamma^{\prime}$ chains. Thromb. Res. 13:467-475.

37. Kudryk, B., A. Rohoza, M. Ahadi, J. Chin, and M. E. Wiebe. 1984. Specificity of a monoclonal antibody for the $\mathrm{NH}_{2}$-terminal region of fibrin. Mol. Immunol. 21:89-94.

38. Skogen, W. F., and G. D. Wilner. 1986. A simple one-step HPLC procedure for the purification of the $\mathrm{NH}_{2}$-terminal plasmin-derived B $\beta 1-42$ peptide of human fibrinogen. Thromb. Res. 41:161-166.

39. Merrifield, R. B. 1965. Automated synthesis of peptides. Solid phase peptide synthesis, a simple and rapid synthetic method, has now been automated. Science (Wash. DC). 150:178-185.

40. Ulrich, M. M., B. Furie, M. R. Jacobs, C. Vermeer, and B. C. Furie. 1988. Vitamin K-dependent carboxylation. A synthetic peptide based upon the $\gamma$-carboxylation recognition site sequence of the prothrombin propeptide is an active substrate for the carboxylase in vitro. J. Biol. Chem. 263:9697-9702.

41. Gimbrone, M. A. Jr., R. S. Cotran, and J. Folkman. 1974. Human vascular endothelial cells in culture. Growth and DNA synthesis. J. Cell Biol. 60:673-684.

42. Wagner, D. D., J. B. Olmsted, and V. J. Marder. 1982. Immunolocalization of von Willebrand protein in Weibel-Palade bodies of human endothelial cells. J. Cell Biol. 95:355-360.

43. Wagner, D. D., and V. J. Marder. 1984. Biosynthesis of von Willebrand protein by human endothelial cells: processing steps and their intracellular localization. J. Cell Biol. 99:2123-2130.

44. Blomback, B., B. Hessel, D. Hogg, and L. Therkildsen. 1978. A two-step fibrinogen-fibrin transition in blood coagulation. Nature (Lond.). 275:501-505.

45. Furlan, M., C. Rupp, and E. A. Beck. 1983. Inhibition of fibrin polymerization by fragment $\mathrm{D}$ is affected by calcium, Gly-Pro-Arg and Gly-His-Arg. Biochim. Biophys. Acta. 747:25-32.

46. Belew, M., B. Gerdin, J. Porath, and T. Saldeen. 1978. Isolation of vasoactive peptides from human fibrin and fibrinogen degraded by plasmin. Thromb. Res. 13:983-994. 
47. Rowland, F. N., M. J. Donovan, P. T. Picciano, G. D. Wilner, and D. L. Kreutzer. 1984. Fibrin-mediated vascular injury: identification of fibrin peptides that mediate endothelial cell retraction. Am. J. Pathol. 117:418-428.

48. Andersson, R. G. G., K. Saldeen, and T. S. Saldeen. 1983. A fibrinogen derived pentapeptide induces vasodilation, prostacyclin release and an increase in cyclic AMP. Thromb. Res. 30:213-218.

49. Senior, R. M., W. F. Skogen, G. L. Griffin, and G. D. Wilner. 1986. Effects of fibrinogen derivatives upon the inflammatory response. Studies with human fibrinopeptide B. J. Clin. Invest. 77:1014-1019.

50. Skogen, W. F., R. M. Senior, G. L. Griffin, and G. D. Wilner. 1988. Fibrinogen-derived peptide $\mathrm{B} \beta 1-42$ is a multidomained neutrophil chemoattractant. Blood. 71:1475-1479.
51. Saldeen, K., N. Cristie, W. R. Nelson, and H. Z. Moval. 1985. Effect of a fibrin(ogen)-derived vasoactive peptide on polymorphonuclear leukocyte migration. Thromb. Res. 37:85-89.

52. Richardson, D. L., D. S. Pepper, and A. B. Kay. 1976. Chemotaxis for human monocytes by fibrinogen-derived peptides. $B r . J$. Haematol. 32:507-513.

53. Gerdin, B., T. Saldeen, W. Roszkowski, S. Szmigielski, J. Stachurska, and M. Kopec. 1980. Immunosuppressive effect of vasoactive peptides derived from human fibrinogen. Thromb. Res. 18:461-468.

54. Plow, E. F., D. Freaney, and T. S. Edgington. 1982. Inhibition of lymphocyte protein synthesis by fibrinogen-derived peptides. J. Immunol. 128:1595-1599.

55. Chen, C. S., S. H. Chou, and P. Thiagarajan. 1988. Fibrin(ogen) peptide $B \beta 15-42$ inhibits platelet aggregation and fibrinogen binding to activated platelets. Biochemistry. 27:6121-6126. 